\title{
Farm related and wild animals inflicted injuries related to orthopaedics in Eastern Nepal: Epidemiology and prospects for control
}

\author{
S Bajracharya ${ }^{1}$, B P Shrestha ${ }^{2}$ \\ Department of Orthopaedics, KIST Medical College \& Teaching Hospital, Gwarko, Lalitpur ${ }^{1}$ \\ Department of Orthopaedics, B.P. Koirala Institute of Health Sciences, Dharan, $\mathrm{Nepal}^{2}$
}

\begin{abstract}
Background: Farm related and animal inflicted injuries are common in Nepal. Objective: To assess the pattern of farm related and wild animal inflicted injury in patients presenting to B.P. Koirala Institute of Health Sciences. Method: This prospective observational study of farm related and wild animals inflicted injuries related to Orthopaedics, conducted from May 2005 to April 2007 at Department of Orthopaedics of B.P. Koirala Institute of Health Sciences Dharan, Nepal, consisting of 87 patients admitted to the Orthopaedic ward of BPKIHS, is presented. The preformed structured proforma were used to record the data and, later those records were analyzed. Result: Altogether 78 domestic related injuries and 9 wild animal related injuries were recorded in the recruitment a period of one year. Twenty-three femoral fractures, 14 humeral fractures, 11 cervical spine injuries, 10 leg bone fractures, 9 forearm fractures were found. Fall from buffalo, hit by buffalo were common cause of injuries in domestic related injuries whereas hit / kick by elephant, attack by bear were causes of wild animal related injuries. All adolescents and adults, irrespective of age or sex, should be the target groups for community education and intervention programs for prevention of such injuries. Conclusion: Femoral fractures were the most common bone injury among farm related and animal inflicted injury.
\end{abstract}

Key words: Domestic, farm, public health, wild animals

\section{Introduction}

Farm related and animal inflicted injury are common. One study showed injury rates for farming and non-farming sources, respectively, to be 1,683 and 6,980 per

\footnotetext{
Address of correspondence

Dr. Suraj Bajracharya

Associate Professor

Department of Orthopaedics

KIST Medical College \& Teaching Hospital

E-mail: drsurajbajra@gmail.com
}

100,000 persons. Animals (40\%) were the primary sources of the farming operation related injuries; sports/recreation sources $(61 \%)$ were associated primarily with nonfarming related injuries. Of the farming and non-farming operation related injury cases, $83 \%$ and $90 \%$, respectively, required some 
type of health care; moreover, $17 \%$ and $24 \%$, respectively, were restricted from regular activities for one month or more. ${ }^{1}$

Cases of orthopedic related injuries inflicted by farm related and wild animals are frequently encountered in Emergency room and Outdoor Patients Room of BPKIHS, a tertiary care center of Eastern region of Nepal. This study is focused on collecting data regarding the type of domestic and wild animals inflicted injuries. The sociodemography of the affected patients, the type of injuries and its severity is noted. The purpose of this effort was to identify the incidence and consequences of animal inflicted orthopaedic related injuries and their potential risk factors. This study helps to assess the gravity of the problem and this area calls for preventive action.

\section{Methods}

This study was conducted in the Department of Orthopaedics, B.P. Koirala Institute of Health Sciences Dharan, Nepal, a tertiary care hospital, from $1^{\text {st }}$ May 2005 to $30^{\text {th }}$ April 2007.

All the patients attending emergency room and outdoor patient room of BPKIHS with farm related and wild animal inflicted orthopaedic related injuries were included in the study. Variables noted were: sociodemography of the patient (age, sex, occupation, address, cause of injury), type of injury, anatomical structures inflicted, neurovascular structures severance, surgical interventions done, follow up of 3 wks, 6 wks and 3 months, total expenses for the treatment (direct cost). In a pre formed proforma, and entered into excel. The entered data is analyzed with the help of EPI INFO.

\section{Results}

The study consists of 26 female and 61 male with mean age of $44.269 \pm 23.425 \mathrm{yrs}$ and $38.06 \pm 20.88$ yrs (P-value $=0.2248)$. Mean duration of reporting time to hospital is 67.72 hrs with SD of 106.47. Commonly farmers, housewives and students were involved in such type of injuries and details as shown in Table 1.

Table 1: Showing different occupations of study population

\begin{tabular}{|l|c|c|}
\hline Occupation & Frequency & Percent \\
\hline Farmer & 36 & $41.4 \%$ \\
\hline Housewife & 21 & $24.1 \%$ \\
\hline Laborer & 7 & $8.0 \%$ \\
\hline Serviceman & 1 & $1.1 \%$ \\
\hline Shopkeeper & 2 & $2.3 \%$ \\
\hline Student & 20 & $23.0 \%$ \\
\hline Total & 87 & $100.0 \%$ \\
\hline
\end{tabular}

In the study, 78 patients were found to be injured due to domestic animal related injuries where as 9 were due to wild animal 
related injuries. Seven patients were brought dead in emergency unit due to attack by wild elephants from various districts of Eastern Nepal. Mode of injuries by animals with frequency in details is shown in table 2.

Table 2: Showing mode of injury by domestic and wild animals

\begin{tabular}{|l|c|c|}
\hline \multicolumn{1}{|c|}{ Mode } & Frequency & Percent \\
\hline Bear Bite & 4 & $4.6 \%$ \\
\hline $\begin{array}{l}\text { Dragged by the } \\
\text { rope of Bull }\end{array}$ & 2 & $2.3 \%$ \\
\hline Fall from Buffalo & 17 & $19.5 \%$ \\
\hline $\begin{array}{l}\text { Fall from bullock } \\
\text { cart hit by Bull }\end{array}$ & 5 & $5.7 \%$ \\
\hline $\begin{array}{l}\text { Fall from Cart and } \\
\text { Hit by Bull }\end{array}$ & 1 & $1.1 \%$ \\
\hline Hit and step by Ox & 1 & $1.1 \%$ \\
\hline $\begin{array}{l}\text { Hit and thrown by } \\
\text { Elephant }\end{array}$ & 1 & $1.1 \%$ \\
\hline Hit by buffalo & 16 & $18.4 \%$ \\
\hline Hit by Bull & 9 & $10.3 \%$ \\
\hline Hit by Bull Horn & 1 & $1.1 \%$ \\
\hline Hit by cow & 11 & $12.6 \%$ \\
\hline Hit by Elephant & 4 & $4.6 \%$ \\
\hline Hit by goat & 2 & $2.3 \%$ \\
\hline Hit by Horse & 1 & $1.1 \%$ \\
\hline Hit by Ox & 10 & $11.5 \%$ \\
\hline Thrown by Bull & 1 & $1.1 \%$ \\
\hline Trapped in rope by & & $1.1 \%$ \\
\hline OX and hit & 1 & \\
\hline
\end{tabular}

Most of the patients reporting to our hospital were from Terai districts followed by hilly districts of Eastern Nepal as showed in Table 3.

Table 3: Showing number of patients from different districts (region wise)

\begin{tabular}{|l|l|l|}
\hline Districts & Region & Frequency \\
\hline Siraha & Terai & 19 \\
\hline Sunsari & Terai & 15 \\
\hline Saptari & Terai & 13 \\
\hline Morang & Terai & 11 \\
\hline Jhapa & Terai & 11 \\
\hline Dhanusha & Terai & 7 \\
\hline Dhankuta & Hilly & 3 \\
\hline Udayapur & Hilly & 3 \\
\hline Bhojpur & Hilly & 2 \\
\hline Ilam & Hilly & 1 \\
\hline Terathum & Hilly & 1 \\
\hline Mahottari & Terai & 1 \\
\hline
\end{tabular}

Table 4 shows the different part of the limbs injured due to domestic and wild animal inflicted injuries. Among them, 23 femoral fractures, 14 humeral fractures, 11 cervical spine injuries, 10 leg bone fractures, 9 forearm fractures were found. Unfortunately, all the cervical spine patients had traumatic quadriparesis. Twenty-three patients had open fractures whereas 50 patients had closed fractures. Among open fractured patients, 5 had neurovascular deficit and 10 had tendon injuries. 


\section{Table 4: Showing anatomical regions injured}

\begin{tabular}{|c|c|}
\hline Anatomical regions involved & $\begin{array}{l}\text { No. of } \\
\text { injuries }\end{array}$ \\
\hline $\begin{array}{l}\text { Arm and shoulder } \\
\text { Dislocation of } \\
\text { shoulder } \\
\text { Fracture humerus } \\
\text { Inter-condylar } \\
\text { fracture } \\
\text { Fracture around } \\
\text { humeral head } \\
\text { Others }\end{array}$ & 19 \\
\hline $\begin{array}{l}\text { Forearm and hand } \\
\qquad \begin{array}{l}\text { Fracture both bones } \\
\text { forearm } \\
\text { Fracture radius } \\
\text { Fracture ulna } \\
\text { Hand fractures } \\
\text { Others }\end{array}\end{array}$ & 12 \\
\hline $\begin{array}{l}\text { Thigh and hip } \\
\text { Inter-trochanteric } \\
\text { fracture } \\
\text { Dislocation of hip } \\
\text { Fracture femur } \\
\text { Fracture distal end } \\
\text { femur } \\
\text { Others }\end{array}$ & 29 \\
\hline $\begin{array}{l}\text { Knee / Leg and Foot } \\
\text { Fracture tibial plateau } \\
\text { Fracture both bone } \\
\text { leg } \\
\text { Fracture Distal end }\end{array}$ & 13 \\
\hline
\end{tabular}

\begin{tabular}{|c|c|c|}
\hline & $\begin{array}{l}\text { tibia fibula } \\
\text { Fracture around foot } \\
\text { Others }\end{array}$ & \\
\hline Spine & $\begin{array}{l}\text { Cervical injuries and } \\
\text { fracture } \\
\text { Dorsolumbar fracture } \\
\text { Lumbar fracture } \\
\text { Others }\end{array}$ & 14 \\
\hline
\end{tabular}

Thirty-six patients were treated conservatively whereas rest of the patients was treated with operative measures. Closed reduction and immobilization was done with Plaster of paris casts/slabs in the patients managed with conservative treatment. Different internal and external fixation devices (plates and screws, nails, external fixators, pins) were used to stabilize femoral fractures, leg bone fractures, humeral fractures, forearm bone fractures. Direct cost incurred due to the injuries (hospital stay+ drugs + operative charges and implants/ plaster of paris) was NRs. $8524.4253 \pm 4700.8836$ with minimum of NRs. 2000 to NRs. 19500.

\section{Discussion}

The main findings of the study is that, farm related and animal inflicted injury most commonly involve femur and humerus.

This study attempted to assess various kinds of farm and wild animal related limb injuries in Eastern Nepal. This study is intended as 
guidance for those who need a broad overview of the subject of such type of injury occurrence and prevention in Nepal, for example in preparation for the development of injury control programmes or to help identify issues requiring further research in this field.

Rasmussen $\mathrm{K}$ et al. $^{3}$ examined the effects of a 4-year randomized intervention program that combined a safety audit with safety behavior training in the prevention of farm injuries. From a random sample of farms in the county of Ringkoebing, Denmark, 393 farms with 1597 residents and employees participated in a weekly self-registration of work-related accidents and injuries during 1 year. This intervention, which focused on safety behavior and was performed as a randomized controlled trial, was followed by a substantial reduction in the number of farm injuries. The reduction was particularly marked for the more severe injuries demanding medical treatment. Our set up is totally different from thesis. So it may be difficult to compare and plan for prevention of farm injuries.

A one-year prospective survey was conducted to study the incidence of and potential risk factors for farm-related injuries in Eastern Ontario. The overall farm injury rate was 7.0 persons injured per 100 personyears (95\% C.I.: 4.9,9.1, $n=547)$. Common patterns of injury they found by ICD-9-E-Code included accidents caused by farm machinery (E919.0), accidental falls (E880-8), and injuries caused by animals (E906). Because of the use of machinery in their agricultural set up, their findings are different from ours. Studies from other developed countries have shown that agriculture is among the most dangerous occupational sectors in terms of work-related deaths. Pickett $\mathrm{W}$ et al. describe the occurrence of fatal work-related farm injuries in Canada and compare these rates with those in other Canadian industries. There were 503 deaths from work-related farm injuries during the study period, for an overall annual rate of 11.6 deaths per 100,000 farm population. Since one is a hospital based study assessing death rates was not our objective. However, there were seven patients who were brought dead during the study period. Compared with other industries, agriculture appears to be the fourth most dangerous in Canada in terms of fatal injury, behind mining, logging and forestry, and construction. Canada now has a national registry for the surveillance of fatal farm injuries. Farming clearly is among the most dangerous occupations in Canada in terms of fatal work-related injuries. Secondary analyses of data from this registry suggest priorities for prevention, continued surveillance and in-depth research. ${ }^{5}$ 


\section{Conclusion}

From the present study and different studies searched from literature shows that farm related and wild animals related injuries are one of the major factors of injury burden to most of the agriculture based developing countries. Therefore, these types of injuries warrants immediate action for control by different preventive measures mainly primary prevention by educating adolescents and adults groups associated with farming occupations.

\section{References}

1. Gerberich SG, Gibson RW, French LR, Renier CM, Lee TY, Carr WP, Shutske J. Injuries among children and youth in farm households: Regional Rural Injury StudyI. Inj Prev. 2001; 7(2):117-22.
2. Nordberg E. Injuries as a public health problem in sub-Saharan Africa: epidemiology and prospects for control. East Afr Med J. 2000; 77(12 Suppl):S143.

3. Rasmussen K, Carstensen O, Lauritsen JM, Glasscock DJ, Hansen ON, Jensen UF. Prevention of farm injuries in Denmark. Scand J Work Environ Health. 2003; 29(4):288-96.

4. Brison RJ, Pickett CW. Non-fatal farm injuries on 117 eastern Ontario beef and dairy farms: a one-year study. Am J Ind Med. 1992; 21(5):623-36. .

5. Pickett W, Hartling L, Brison RJ, Guernsey JR. Fatal work-related farm injuries in Canada, 1991-1995. Canadian Agricultural Injury Surveillance Program. CMAJ.

1999:29;160(13):1843-8. 